\title{
Salinity affects flag leaf chlorophyll and yield attributes of rice genotypes
}

\author{
M. S. Rahman, M. A. Haque and M. T. Islam
}

Crop Physiology Division, Bangladesh Institute of Nuclear Agriculture (BINA), Mymensingh, Bangladesh

\begin{abstract}
Four rice genotypes Binadhan-8, PBRC-37, NERICA-1 and NERICA-10 were evaluated under four levels of salinity, i.e., control, 6, 9 and $12 \mathrm{dSm}^{-1}$ to understand their effects on flag leaf chlorophyll content and yield attributes of these genotypes. The experiment was established under polythene shade to avoid rain water in the pot yard of Crop Physiology Division, Bangladesh Institute of Nuclear Agriculture, Mymensingh. NERICA-1 produced the highest grain yield hill-1 due to higher number of panicle hill-1, panicle length and 1000 grain weight against salinity (average of 0, 6, 9 and $12 \mathrm{dSm}^{-1}$ ) which was followed by PBRC-37. The interaction effect of different levels of salinity and genotypes on different parameters (effective tillers hill-1, filled grains hill ${ }^{-1}$ and grain wt. hill-1) decreased slowly from control to $9 \mathrm{dSm}^{-1}$ and then after it decreased sharply at $12 \mathrm{dSm}^{-1}$. NERICA1 and PBRC-37 were relatively high yielding at $12 \mathrm{dSm}^{-1}$ compared to other two genotypes. Flag leaf chlorophyll $a$, chlorophyll $b$ and total chlorophyll content were high in NERICA-1 and NERICA-10 compared to Binadhan-8 and PBRC-37. NERICA-1 and NERICA-10 showed higher chlorophyll $a$, chlorophyll $b$ and total chlorophyll than Binadhan-8 and PBRC-37 in all salinity levels showed their higher chlorophyll stability against salinity. Furthermore, NERICA-1 and PBRC-37 showed salt tolerance up to $9 \mathrm{dSm}^{-1}$ where NERICA-1 and NERICA-10 showed higher chlorophyll stability than Binadhan-8 and PBRC-37 against salinity.
\end{abstract}

Key words: Rice genotypes, yield attributes, chlorophyll and salt tolerance

Please cite this article as: Rahman, M. S., Haque, M. A. \& Islam, M. T. (2015). Salinity affects flag leaf chlorophyll and yield attributes of rice genotypes. Journal of Bioscience and Agriculture Research 04(02), 80-85.

This article is distributed under terms of a Creative Common Attribution 4.0 International License.

\section{Introduction}

Salinity is a global problem for agriculture including Bangladesh. According to salinity survey findings, salinity monitoring information and interpretation of Land and Soil Resource Utilization Guide (Upazilla Nirdeshika, sub-district manual), about 0.170 million hectares $(20.4 \%)$ new land has been affected by various degrees of salinity during last three decades which is increasing due to rising sea level (Ahsan, 2000). The staple food of Bangladesh is rice which can grow hardly in saline land due to adverse physiological activity in rice plant. Chlorophyll is a major component of plant which captures sunlight and it plays a major role to produce carbohydrate for plant by photosynthesis (Streitweiser \& Heathcock, 1981; Stryer, 1975). Chen \& Filippis (2001) numerous physiological responses of plant to salt stress including cellular and whole plant responses. Structural components of plants including leaf 
structure that undergo changes due to salinity are intimately linked to physiological and biochemical activities of the plant (Cushman \& Bohnert, 1995; Bohnert \& Jensen, 1996). The main causes of growth reduction under salt stress may be the unfavorable morphological structures changes in association with physiological modifications. Accumulation of salt in growing leaves has been correlated with photosynthetic reduction and with ultra-structural and metabolic damages and consequent death of leaves (Yeo \& Flowers, 1986). Another reason for reduction in starch concentration in plant tissue is the direct effects of decreased $\mathrm{CO}_{2}$ assimilation caused by reduction in stomatal conductance and content of chlorophyll in plant tissue under salt stress (Moradi \& Ismail, 2007). Chlorophyll acts as key component in the metabolic activities of the plant and finally to the yield. It is the major light absorbing pigments of the plants (Lehninger, 1982). Flag leaves play a major role in synthesis and translocation of photo assimilates to the rice seeds, affecting grain yield. Removal of the rice flag leaf at any stage after panicle emergence was reported to cause significant reduction in grain yield (Singh \& Ghosh, 1981). About $45 \%$ of rice grain yield losses due to removal of flag leaf (Abou-Khalifa et al., 2008). According to Mae (1997), 60-90\% of total carbon in the panicles at harvest is derived from photosynthesis after heading, while $80 \%$ or more of nitrogen $(\mathrm{N})$ in the panicles at harvest is absorbed before heading and remobilized from vegetative organs. The effects of salinity on chlorophyll synthesis and integrity seems to vary with the level of salt stress, as few reports suggested an accelerated rate of biosynthesis and higher concentrations during vegetative growth (Asch et al., 2000; Santo, 2004), however, significant differences between genotypes were sometimes observed regarding the effects of salt stress on chlorophyll concentration in leaves (Rout et al., 1997; Datta et al., 2009). However, detailed studies on genetic differences in these traits are still scanty. This article evaluated the variation in chlorophyll concentration in rice genotypes known to contrast in their tolerance to salt stress and to further investigate whether these changes are associated with tolerance.

\section{Materials and Methods}

A pot experiment was carried out at Bangladesh institute of Nuclear Agriculture (BINA) pot experiment yard with four rice genotypes viz. Binadhan-8, PBRC-37, NERICA-1 and NERICA-10 in Boro season 2012. The experiment was conducted following completely randomized design with four replications. To establish the experiment perforated pots were filled up with $8 \mathrm{~kg}$ well mixed soil with cow dung and fertilizer @ $50 \mathrm{~N}, 25 \mathrm{P}$ and $25 \mathrm{~K} \mathrm{mg} \mathrm{kg}^{-1}$ of soil. A polythene shade was established above the experiment area to avoid the rain water. Eight filled pots were placed in each glass fibre tray and the tray was filled with water up to the neck of the pot. Sprouted three seeds were sown in each pot. Raw salt collected from sea shore was used to achieve the EC in the experiment. Four levels of salinity viz. $0,6,9$ and $12 \mathrm{dSm}^{-1}$ were imposed at maximum tillering stage and remained up to the harvest. Chlorophyll content was determined from the flag leaf samples at flowering stage using the method of Coombs et al. (1985). Chlorophyll was extracted from fresh flag leaves $(0.05 \mathrm{~g})$ by grinding the sample with $10 \mathrm{ml} 80 \%$ acetone in a mortar. The mixture was then centrifuged at $5000 \mathrm{rpm}$ for 10 minutes. The supernatant was collected and taken to read for absorbance at 663 and 645 nanometers. The amount of chlorophyll was calculated using the following formulae suggested by Coombs et al. (1985).

$$
\begin{aligned}
& \text { Chlorophyll } \mathrm{a}=12.7 \times \mathrm{D} 663-2.69 \times \mathrm{D} 645 \\
& \text { Chlorophyll } \mathrm{b}=22.90 \times \mathrm{D} 645-4.68 \times \mathrm{D} 663 \\
& \text { Total Chlorophyll }=20.2 \times \mathrm{D}_{645}+8.02 \times \mathrm{D}_{663}
\end{aligned}
$$

Yield and yield attributes data have been collected at final harvest and analyzed statistically following Completely Randomized Design by MSTAT-C computer package programme developed by Russel (1986). The treatment means were adjudged by Duncan's Multiple Range Test (DMRT). 


\section{Results and Discussion}

Higher plant height, number of panicle hill-1 ${ }^{-1}$ panicle length, 1000 grain weight resulting higher grain weight hill-1 in NERICA-1 which was followed by PBRC-37 and NERICA-10. Binadhan-8 recorded the lowest grain yield hill-1 due to lower panicle hill-1 ${ }^{-1}$ panicle length and 1000 grain weight. NERICA-10 and NERICA-1 produced higher unfilled grain panicle ${ }^{-1}$ than Binadhan-8 and PBRC-37 (Table 01).

Plant height, total tiller hill-1 ${ }^{1}$, panicle hill-1 ${ }^{-1}$ filled grain and grain wt. hill-1 decreased significantly with increasing salinity level except panicle length and unfilled grain panicle ${ }^{-1}$ due to the effect of different levels of salinity. Reduction rate of different yield contributing characters compare to control revealed that most of the parameters decreased slowly from control to $9 \mathrm{dSm}^{-1}$ and after that it reduced sharply but length of panicle not reduce mass more up to $12 \mathrm{dS} \mathrm{m}^{-1}$. The highest reduction rate compared to control was observed in grain weight hill-1 $(38-77 \%)$ where the minimum in panicle length (3.25$4.22 \%$ ). The loss of potential spikelet has been attributed to a competition for carbohydrate supply between vegetative growth and developing panicles and among spikelet within panicle (Murty \& murty, 1982; Zeng \& Shannon, 2000b). Maas and Grieve (1990) observed reduction of spikelet and kernel number per spike under the influence of root zone salinity. Salinity often reduces shoot growth more than root growth and can reduce the number of florets per ear, increase sterility and affect the time of flowering and maturity in rice (Lauchli \& Epstein, 1990; Khatun et. al., 1995; Lauchli \& Grattan, 2007). Results indicated that increase in salinity decreases grain yield drastically due to decrease in no. of panicle hill-1 ${ }^{-1}$ filled grain panicle ${ }^{-1}$ and 1000 grain weight. High effectiveness of salinity on number of grains has been reported by many researchers (Beatriz et. al., 2001). The yield components of rice plant were seriously affected by salinity (Zeng \& Shannon, 2000a). Salinity of water or soil decreases number of grains in panicle (Beatriz et al., 2001). Mahmood et al. (2009) studied the effect of salinity on rice and stated that increasing salinity significantly reduced the grain filling capacity. Panicle length was the highest at $9 \mathrm{dSm}^{-1}$ Binadhan-8. Thus, results revealed that NERICA- 1 and PBRC37 were found relatively better under salinity up to $12 \mathrm{dSm}^{-1}$ with respect to yield and yield attributes.

Among four genotypes, NERICA-1 and NERICA-10 had higher chlorophyll $\mathrm{a}$, chlorophyll $\mathrm{b}$ and total chlorophyll than Binadhan-8 and PBRC-37 where chlorophyll a/b ratio showed higher in Binadhan-8 and PBRC-37. Chlorophyll a, total chlorophyll and chlorophyll $a / b$ ratio decreased with increasing of salinity level except chlorophyll b (Table 02). The interaction effect of genotypes and salinity levels also accounted significant variations at $\mathrm{P} \leq 0.01$ (Figure 01). NERICA-1 measured higher chlorophyll a, chlorophyll $b$ and total chlorophyll compared to control in all salinity levels where NERICA-10 as counted the highest content of chlorophyll a, chlorophyll b and total chlorophyll up to $9 \mathrm{dSm}^{-1}$ and then it decreased at $12 \mathrm{dSm}^{-1}$. Concentration of different chlorophyll was found higher under salt stress than under control condition which agreed with previous observation (Asch et al., 2000; Santo, 2004). Binadhan-8 and PBRC-37 measured increasing trend in chlorophyll a, chlorophyll $b$ and total chlorophyll content up to $6 \mathrm{dSm}^{-1}$ and then after it decreased. Binadhan-8 and PBRC-37 showed higher chlorophyll a/b ratio at all levels of salinity than NERICA-1 and NERICA-10. Islam (2001) found less chlorophyll $b$ than chlorophyll a in salt affected crops and thus increased the chlorophyll $a / b$ ratio. Abdullah et al. (2001) also found a significant reduction in both chlorophyll a and chlorophyll b content in different parts of the rice leaves at saline condition in IR 28. Earlier studies have indicated larger decline in total chlorophyll b content due to salinity stress in susceptible than tolerant genotypes of different crops (Lahiri et al., 1996). Salinity was found to enhance the chlorophyllase activity which results in lowering the chlorophyll content (Rao \& Rao, 1981; Reddy \& Vora, 1986) and it may also partly due to interference of salt ions with the de novo synthesis of proteins and the structural component of chloroplast. 
Table 01. Effect of salinity on morphological and yield attributes at reproductive stage in 4 rice genotypes

\begin{tabular}{|c|c|c|c|c|c|c|c|c|}
\hline Treatments & $\begin{array}{c}\text { Plant } \\
\text { Height } \\
(\mathrm{cm})\end{array}$ & $\begin{array}{l}\text { Total } \\
\text { tiller/hill } \\
\text { (no.) }\end{array}$ & $\begin{array}{c}\text { Panicle } \\
\text { /hill } \\
\text { (no.) }\end{array}$ & $\begin{array}{c}\text { Panicle } \\
\text { length } \\
(\mathrm{cm})\end{array}$ & $\begin{array}{c}\text { Filled } \\
\text { grain/ } \\
\text { Panicle } \\
\text { (no.) }\end{array}$ & $\begin{array}{l}\text { Unfilled } \\
\text { grain/ } \\
\text { panicle } \\
\text { (no) }\end{array}$ & $\begin{array}{c}1000 \\
\text { grain } \\
\text { wt. (g) }\end{array}$ & $\begin{array}{c}\text { Grain } \\
\text { wt./hill } \\
\text { (g) }\end{array}$ \\
\hline \multicolumn{9}{|l|}{ Genotypes } \\
\hline Binadhan-8 & $76.44 \mathrm{~d}$ & $23.88 \mathrm{c}$ & $11.69 \mathrm{c}$ & $20.79 \mathrm{~d}$ & $73.73 \mathrm{a}$ & $20.65 \mathrm{~b}$ & $20.53 c$ & $7.46 c$ \\
\hline PBRC-37 & 87.1 & 27.8 & & & $74.3 \mathrm{a}$ & $19.65 \mathrm{c}$ & $22.06 \mathrm{~b}$ & $8.89 \mathrm{~b}$ \\
\hline NER & 90.4 & & & & $70.86 \mathrm{~b}$ & $22.38 \mathrm{a}$ & $22.31 \mathrm{a}$ & $10.38 \mathrm{a}$ \\
\hline NERICA 10 & $77.66 \mathrm{c}$ & 24 & $9 \mathrm{c}$ & 20 & $60.9 c$ & $22.08 \mathrm{a}$ & $22.13 \mathrm{ab}$ & $8.39 \mathrm{~b}$ \\
\hline \multicolumn{9}{|c|}{ Salinity $\left(\mathrm{dSm}^{-1}\right)$} \\
\hline Control & 92.22 & 8 & & 2 & $89.74 \mathrm{a}$ & $13.09 \mathrm{~d}$ & $25.88 \mathrm{a}$ & $15.15 a$ \\
\hline 6 & $84.94 \mathrm{~b}$ & 26.6 & $13.13 \mathrm{~b}$ & $20.76 \mathrm{c}$ & $75.07 \mathrm{~b}$ & $13.88 \mathrm{c}$ & $22.01 \mathrm{~b}$ & $9.36 \mathrm{~b}$ \\
\hline 9 & $82.35 \mathrm{c}$ & $25.19 \mathrm{c}$ & $12.44 \mathrm{c}$ & $21.57 \mathrm{a}$ & $65.79 \mathrm{c}$ & $20.73 \mathrm{~b}$ & $20.19 c$ & $7.14 \mathrm{c}$ \\
\hline 12 & $72.16 \mathrm{~d}$ & $22.13 \mathrm{~d}$ & $9.5 \mathrm{~d}$ & $20.66 \mathrm{~d}$ & $49.19 \mathrm{~d}$ & $37.06 \mathrm{a}$ & $18.96 \mathrm{~d}$ & $3.46 \mathrm{~d}$ \\
\hline
\end{tabular}

Either in genotype or in salinity, in a column figures having similar letter(s) do not differ significantly at 5\% level of probability by DMRT.

Table 02. Chlorophyll of flag leaf at flowering stage of different rice genotypes as affected by salinity

\begin{tabular}{|c|c|c|c|c|}
\hline Genotype & $\begin{array}{l}\text { Chlorophyll a } \\
\text { (mgg-1 } 1 \mathrm{fw})\end{array}$ & $\begin{array}{l}\text { Chlorophyll b } \\
\text { (mgg-1 } 1 \mathrm{fw})\end{array}$ & $\begin{array}{l}\text { Total Chlorophyll } \\
\left(\mathrm{mgg}^{-1} \mathrm{fw}\right)\end{array}$ & Chlorophyll a/b \\
\hline Binadhan 8 & $1.990 \mathrm{~b}$ & $0.686 \mathrm{c}$ & $2.675 \mathrm{c}$ & $2.905 \mathrm{~b}$ \\
\hline PBRC-37 & $1.793 \mathrm{c}$ & $0.602 \mathrm{~d}$ & $2.395 \mathrm{~d}$ & $2.985 a$ \\
\hline Nerica 1 & $2.243 \mathrm{a}$ & $0.827 \mathrm{~b}$ & $3.070 \mathrm{~b}$ & $2.717 \mathrm{c}$ \\
\hline Nerica 10 & $2.290 \mathrm{a}$ & $0.875 \mathrm{a}$ & $3.161 \mathrm{a}$ & $2.640 \mathrm{~d}$ \\
\hline \multicolumn{5}{|c|}{ Salinity Level $\left(\mathrm{dSm}^{-1}\right)$} \\
\hline Control & $2.105 \mathrm{~b}$ & $0.734 \mathrm{c}$ & $2.838 \mathrm{~b}$ & $2.922 \mathrm{a}$ \\
\hline 6 & $2.190 \mathrm{a}$ & $0.789 a$ & $2.980 \mathrm{a}$ & $2.813 \mathrm{~b}$ \\
\hline 9 & $2.003 \mathrm{c}$ & $0.742 \mathrm{~b}$ & $2.743 \mathrm{c}$ & $2.714 \mathrm{c}$ \\
\hline 12 & $2.017 \mathrm{c}$ & $0.724 \mathrm{~d}$ & $2.740 \mathrm{c}$ & $2.798 \mathrm{~b}$ \\
\hline
\end{tabular}

Either in genotype or in salinity, in a column figures having similar letter(s) do not differ significantly at $5 \%$ level of probability by DMRT.
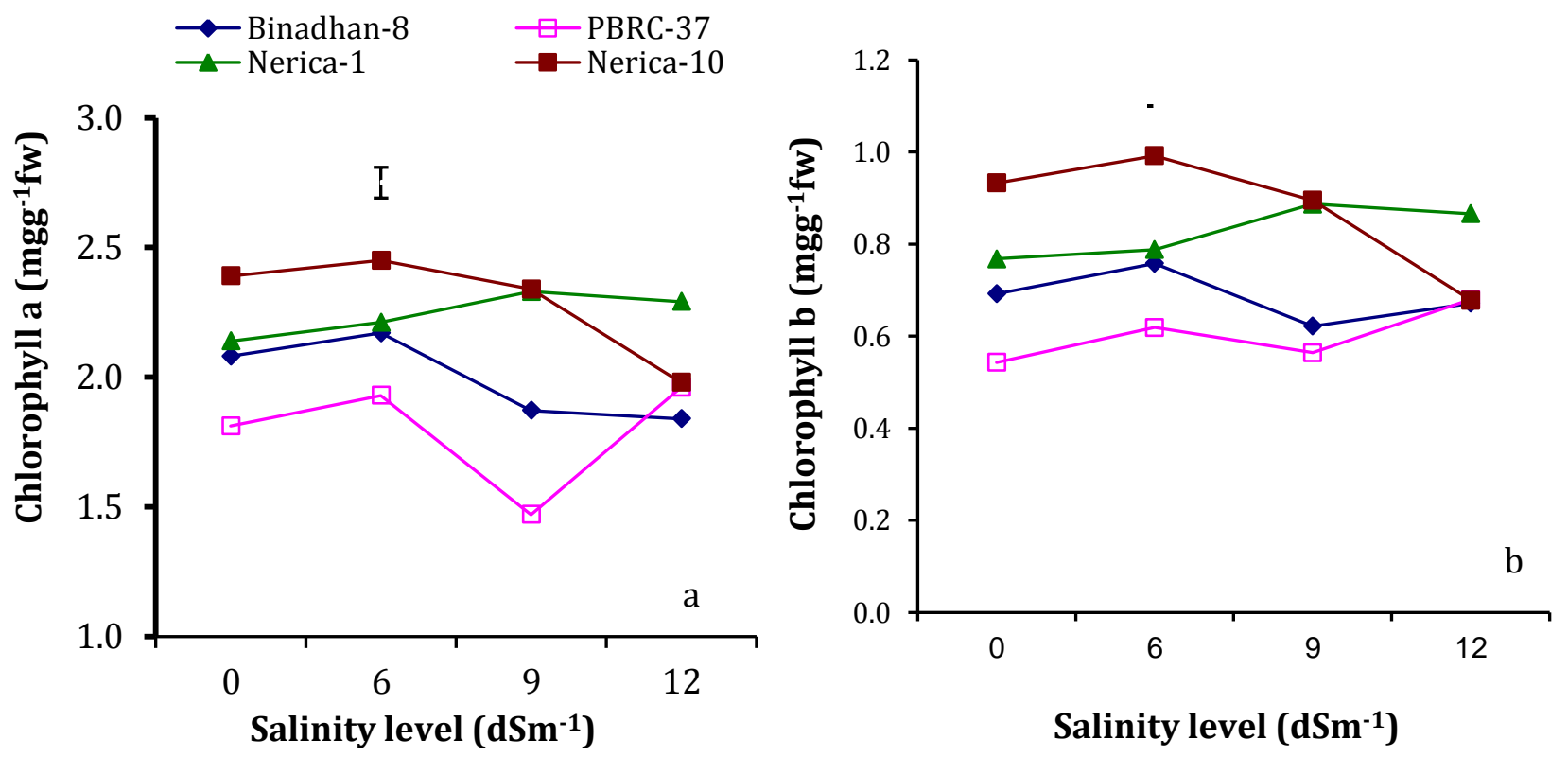

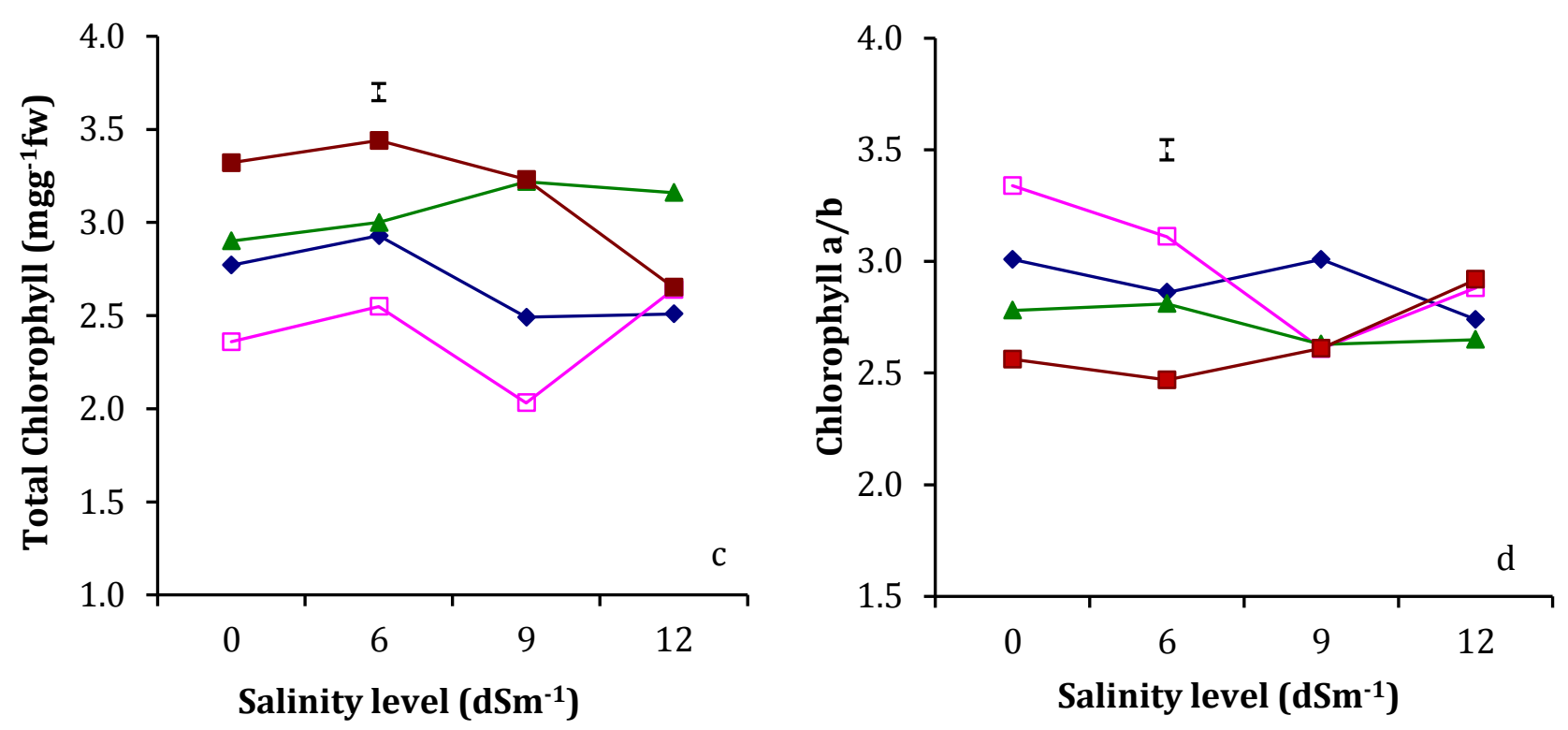

Figure 01. Interaction effect of Chlorophyll of flag leaf at flowering stage of rice genotypes against different levels of salinity (a) Chlorophyll a, (b) Chlorophyll b, (c) Total Chlorophyll and (d) Chlorophyll a/b.

\section{Conclusion}

Results revealed that NERICA-1 and PBRC-37 appeared to be more saline tolerant compared to Binadhan-8 and NERICA-10. NERICA-1 and NERICA-10 were found to possess comparatively higher chlorophyll content in flag leaf irrespective of changes in salinity level which can be used as breeding material for developing high yielding salt tolerant variety.

\section{References}

[1]. Abdullah, Z., Khan, M. A. \& Flowers, T. J. (2001). Causes of sterility in seed set of rice under salinity stress. Journal of Agronomy and Crop Science, 187(1), 25-32.

[2]. Abou-Khalifa, A. A. B., Misra, A. N. \& Salem, A. E. A. K. M. (2008). Effect of leaf cutting on physiological traits and yield of two rice cultivars. African Journal of Plant Science, 2, 147-150.

[3]. Ahsan, M. 2000. Survey, mapping and documentation of soil salinity in Bangladesh. p-13.

[Retrieved 10 July 2015 from http://180.211.164.225/rmis/index.php?t=detail info\&linkid=6635]

[4]. Asch F., Dingkuhn, M. \& Dorffling, K. (2000). Salinity increases $\mathrm{CO}_{2}$ assimilation but reduces growth in field-grown, irrigated rice. Plant and Soil, 218, 1-10.

[5]. Beatriz, G., Pietunand, N. \& Bernstein, N. (2001). Salinity-induced inhibition of leaf elongation in maize is not mediated by changes in cell wall. Plant Physiology, 125, 1419-1428.

[6]. Bohnert, H. J. \& Jensen, R. G. (1996). Strategies in engineering water stress tolerance in plants. Trends in Biotechnology, 14, 89-97.

[7]. Chen, M. D \& Filippis, L. F. D. (2001). Differentially expressed genes identified during salt adaptation in Eucalyptus microarrays: down-regulation of a cDNA sequence coding for alphatabulin. Journal of Plant Physiology, 158, 1195-1202.

[8]. Coombs, J. D. O., Long, S. P. \& Scurlok, J. M. O. (1985). Techniques in Bio-productivity and Photosynthesis ( $2^{\text {nd }}$ ed.). Paragamon International. Oxford. Pp. 223-234.

[9]. Cushman, J. C. \& Bohnert, H. J. (1995). Transcriptional activation of CAM genes during development and environmental stress. In: Crassulacean Acid Metabolism. K. Winter and J. A. C. Smith (Eds.). Springer, Heidelberg, Germany. 
[10]. Datta, J. K., Nag, S., Banerjee, A., \& Mondal, N. K. (2009). Impact of salt stress on five varities of wheat (Triticum aestivum L.) cultivars under laboratory condition. Journal of Applied Science and Environment Management, 13(3), 93-97.

[11]. Islam, M. S. (2001). Morpho-physiology of blackgram and mungbean as influenced by salinity. M.S. Thesis. Dept. of Agron, BSMRAU, Salna, Gazipur. pp. 24-27.

[12]. Khatun, S., Rizzi, C. A. \& flowers, T. J. (1995). Genotypic variation in the effect of salinity on fertility in rice. Plant Soil, 173, 239-2501.

[13]. Lahiri, A. N., Garg, B. K., Vyas, S. P., Katrhju, S. \& Mali, P. C. (1996). Genotypic differences to soil salinity in cluster bean. Arid Soil Research Rehabilition, 10: 333-345.

[14]. Lauchli, A \& Epstein, E. (1990). Plant response to saline and sodic conditions. In: K. K. Tanji (Editor), Agricultural Salinity Assessment and Management. ASCE Manuals and Reports No. 71.ASCE, New York, USA, pp. 1130-1137.

[15]. Lauchli, A \& Grattan, S. R. (2007). Plant growth and development under salinity stress. In: M. A. Jenk, P. M. Hasegawa and S. M. Jain (Editors), Advances in molecular breeding toward drought and salt tolerant crops. Springer, Dordrecht, The Netherlands, pp. 1-32.

[16]. Lehninger, A. L. (1982). Principles of Biochemistry. New York, Worth Publishers, Inc.

[17]. Maas, E. V. \& Grieve, C. M. (1990). Spike and leaf development in salt stressed wheat. Crop Science, 30, 1309-1313.

[18]. Mae, T. (1997). Physiological nitrogen efficiency in rice: Nitrogen utilization, Photosynthesis, and yield potential. Plant and Soil, 196, 201-210.

[19]. Mahmood, M., Latif, T. \& Khan, M. A. (2009). Effect of salinity on growth, yield and yield components in basmoti rice germplasm. Pakistan Journal Botany, 41(6), 3033-3045.

[20]. Moradi F., \& Ismail, A. M. 2007. Responses of photosynthesis, chlorophyll fluorescence and ROSScavenging systems to salt stress during seedling and reproductive stages in rice. Annals of Botany, 99, 1161-1173.

[21]. Murty, P. S. S \& Murty, K. S. (1982). Spikelet sterility in relation to nitrogen and carbohydrate contents in rice. Indian Journal of Plant Physiology, 25, 40-48.

[22]. Rao, G. G. \& Rao, G. R. (1981). Pigment composition and Chlorophyllase activity in pigeonpea (Cajanus indicus) and gingellay (Sesamum indicum L.) under $\mathrm{NaCl}$ salinity. Indian Journal of Experimental Biology, 19: 768-770.

[23]. Reddy, M. P. \& Vora, A. B. (1986). Changes in pigment composition, Hill reaction activity and Saccharides metabolism in Bajra (Pennisetum typhoides) leaves under $\mathrm{NaCl}$ salinity. Photosynthetica, 20, 50-55.

[24]. Rout, N. P., Tripathi, S. B \& Shaw, B. P. (1997). Effect of salinity on chlorophyll and proline contents in three acquatic macrophytes. Biology of Plant, 40, 453-458.

[25]. Russel, D. F. (1986). MSTAT-C Package Programme. Crop and Soil Science Department, Michigan State University, USA.

[26]. Santo, C. V. (2004). Regulation of chlorophyll biosynthesis and degradation by salt stress in sunflower leaves. Science of Horticulture,103, 93- 99.

[27]. Singh, T. \& Ghosh, A. K. (1981): Effect of flag leaf on grain yield of transplanted rice. International Rice Research Institute, 6: 5.

[28]. Streitweiser, A \& Heathcock, C. H. (1981). Introduction to organic chemistry, Mac Millan, New York.

[29]. Stryer, L. (1975). Biochemistry, W. H. Freeman and Co. San Francisco.

[30]. Yeo, A. R \& Flowers, T. J. (1986). Salinity resistance in rice (Oryza sativa) and a pyramiding approach to breeding varieties for saline soils. In: Effect of drought on plant growth. Salt in soils. N. C. Turner and J. B. Passioura (Eds.).CSIRO. Melbourne. Australia, pp. 161-173.

[31]. Zeng, L \& Shannon, M. C. (2000a). Effect of salinity on grain yield and yield components of rice at different seeding densities. Agronomy Journal, 92, 418-423.

[32]. Zeng, L \& Shannon, M. C. (2000b). Salinity effects on seedling growth and yield components of rice. Crop Science, 40, 996-1003. 